\title{
SYNTHESIS AND ANTIDEPRESSANT ACTIVITY OF 2-BROMO-1-(THIETAN-3-YL) IMIDAZOLE- 4, 5-DICARBOXYLIC ACID DERIVATIVES
}

\author{
FERKAT KHALIULLIN ${ }^{*}$, IRINA NIKITINA², ANFISA VALIEVA ${ }^{1}$, ALBINA MIFTAKHOVA ${ }^{2}$, EKATERINA \\ MESCHERYAKOVA ${ }^{3}$, LEONARD KHALILOV ${ }^{3}$
}

\begin{abstract}
1Department of Pharmaceutical Chemistry, Bashkir State Medical University, Lenina Str., 3, 450008, Ufa, Russia, ${ }^{2}$ Department of Pharmacology № 1, Bashkir State Medical University, Lenina Str., 3, 450008, Ufa, Russia, ${ }^{3}$ Laboratory of Structural Chemistry, Institute of Petrochemistry and Catalysis, Russian Academy of Science, Prospekt Oktyabrya, 141, 450075, Ufa, Russia

Email: khaliullin_ufa@yahoo.com
\end{abstract}

Received: 09 Feb 2017 Revised and Accepted: 30 Jun 2017

\section{ABSTRACT}

Objective: Synthesis of the salts and diylidenehydrazides of 2-bromo-1-(thietan-3-yl) imidazole-4,5-dicarboxylic acid to evaluate the antidepressant activities.

Methods: The structures of the synthesised compounds were confirmed by elemental analysis and ${ }^{1} \mathrm{H}$ NMR spectral data. The melting points of the compounds were determined on a Stuart SMP30 apparatus. The X-ray diffraction data for compound IIc were obtained at room temperature on a Xcalibur Gemini Eos. The antidepressant activity was investigated in the tail suspension and forced swimming tests. The locomotor activity and anxiety were studied in the open field test.

Results: All synthesised compounds showed antidepressant activity after single intraperitoneal injection to male mice at doses equimolar to 10 $\mathrm{mg} / \mathrm{kg}$ of imipramine. One of the compounds, 2-bromo-1-(thietan-3-yl) imidazole-4,5-dicarboxylic acid di[(4-hydroxy-3-methoxyphenyl) methylidenehydrazide], reduced the anxiety and decreased the locomotor activity at statistically significant levels. Other compounds did not have sedative and/or stimulating effects.

Conclusion: Among the synthesised 2-bromo-1-(thietan-3-yl) imidazole-4,5-dicarboxylic acid derivatives, compounds with marked antidepressant activity were identified. An obvious advantage of these products is low toxicity.

Keywords: Imidazole-4,5-dicarboxylic acid, Thietane, Diylidenehydrazides, Antidepressant activity

(c) 2017 The Authors. Published by Innovare Academic Sciences Pvt Ltd. This is an open access article under the CC BY license (http://creativecommons.org/licenses/by/4.0/) DOI: http://dx.doi.org/10.22159/ijpps.2017v9i8.17613

\section{INTRODUCTION}

Imidazole derivatives represent a class of drugs widely used in medicine [1]. Nowadays, search for biologically active compounds among derivatives of imidazole, in particular, in a series of imidazole4,5-dicarboxylic acids are in progress. The compounds with antiviral activity have been found among imidazole-4,5-dicarboxylic acid derivatives $[2,3]$. The hydrazinium salt of imidazole-4,5-dicarboxylic acid shows an antibacterial effect [4]. 1-Methylimidazole-4,5dicarbohydrazide is a monoamine oxidase inhibitor [5]

To find new biologic active compounds among 2-bromoimidazole-4, 5-dicarboxylic acid derivatives, the target activity forecast was performed with SARD-21 software. The study showed that 2-bromo1-(thietan-3-yl) imidazole-4,5-dicarboxylic acid salts and diylidenehydrazides may have an antidepressant effect. Depression refers to socially significant diseases, which is due to their high prevalence [6]. The study of the antidepressant activity of known drugs [7] and the search for new sources of antidepressant drugs are continuing [8]. The aim of this study was to synthesise and study the antidepressant activity of 2-bromo-1-(thietan-3-yl) imidazole-4, 5dicarboxylicacid derivatives.

\section{MATERIALS AND METHODS}

\section{Materials}

${ }^{1} \mathrm{H}$ NMR spectra were recorded on a BrukerAM-300 instrument operating at $300 \mathrm{MHz}$. The residual solvent signals were used as internal standards. TLC was carried out on Sorbfil plates with a 4:1:2 1-butanol-acetic acid-water (IIb, IIc) or 1:1 dioxane-ethanol (IVb) mixture or with dioxane (IVa) as the mobile phase. The melting points of the compounds were determined on a Stuart SMP30 apparatus. The X-ray diffraction data for compound IIc were obtained at room temperature on a Xcalibur Gemini Eos diffractometer equipped with an EOS CCD three-dimensional array detector and a monochromated $\mathrm{MoK \alpha}$ radiation (graphite monochromator, MoK $\alpha$ radiation, $\lambda=0.71073 \AA$, $\omega$-scan mode, $2 \theta_{\max }$ $\left.=62^{\circ}\right)$. The data were collected and treated using CrysAlis ${ }^{\operatorname{Pr}}{ }^{\circ}$ Oxford Diffraction Ltd. software, Version 1.171.36.20 [9]. The crystal of compound IIc $\left(\mathrm{C}_{8} \mathrm{H}_{6} \mathrm{Br}_{1} \mathrm{~K}_{1} \mathrm{~N}_{2} \mathrm{O}_{4} \mathrm{~S}_{1}, M=345.21\right)$ is monoclinic. The unit cell parameters are $a=5.4769(4) \AA, b=16.8316(11) \AA$, $c=$ $12.3235(10) \AA, \beta=101.291(7)^{\circ}, V=1114.05(14) \AA^{3}$; space group $\mathrm{P} 21 / \mathrm{n}$ (no. 14); $Z=4 ; \mathrm{D}_{\text {calcd. }}=2.058 \mathrm{mg} / \mathrm{mm}^{3}$. The final R-factors are as follows: $\mathrm{R} 1=0.0579$ for 1914 collected unique reflections with $\mathrm{I}>2 \sigma(\mathrm{I})$ and $w \mathrm{R} 2=0.1709$ for 2683 unique reflections. The structure was solved by the direct method and refined by the full-matrix leastsquares method in the anisotropic approximation for non-hydrogen atoms. The hydrogen atoms were located in a difference Fourier synthesis and refined in the isotropic approximation. The calculations were carried out using the SHELX [10]. The CIF-file is deposited with the Cambridge crystallographic data centre, CCDC No 1452164. A copy of these data is available free of charge on request from CCDC, 12, Union Road, Cambridge, CB2 1EZ, UK (fax: +44 1223 336033, e-mail: deposit@ccdc. cam. ac. uk) or via http://www. ccdc. cam. ac. uk/data_request/cif.

Compounds I and III were synthesised by procedures described in [11]. Compounds IIa and IId-f were synthesised by procedures described in [12].

Dipotassium 2-bromo-1-(thietan-3-yl) imidazole-4,5-dicarboxylate (IIb)

Potassium hydroxide $(0.67 \mathrm{~g}, 12 \mathrm{mmol})$ and compound I (1.0 g, 3 mmol) were dissolved in a mixture of $10 \mathrm{ml}$ of water and $25 \mathrm{ml}$ of ethanol. The reaction mixture was stirred with a magnetic stirrer at 
room temperature for $5 \mathrm{~h}$. The precipitate was filtered off, washed with ethanol, and dried. The product was purified by reprecipitation with acetone from an aqueous solution to give $0.9 \mathrm{~g}$ (78\%) of compound IIb. Mp ( ${ }^{\circ} \mathrm{C}$ ): 270 (decomp); Rf: $0.54 ;{ }^{1} \mathrm{H}$ NMR $\left(\mathrm{D}_{2} \mathrm{O}\right)$ : $3.47-3.53\left(\mathrm{~m}, 2 \mathrm{H}, \mathrm{S}(\mathrm{CH})_{2}\right)$, 4.34-4.41 (m, $\left.2 \mathrm{H}, \mathrm{S}(\mathrm{CH})_{2}\right)$, 5.87$5.96(\mathrm{~m}, 1 \mathrm{H}, \mathrm{NCH})$ ppm; CHN analysis for $\mathrm{C}_{8} \mathrm{H}_{5} \mathrm{~N}_{2} \mathrm{O}_{4} \mathrm{Br}_{1} \mathrm{~S}_{1} \mathrm{~K}_{2} ; \mathrm{C}$ 25.07; H 1.31; N 7.31. Found C 25.41; H 1.30; N 7.28.

\section{Potassium 2-bromo-1-(thietan-3-yl) imidazole-4,5-dicarboxylate (IIc)}

Compound IIb (0.6 g, $1.6 \mathrm{mmol})$ was dissolved in $4 \mathrm{ml}$ of water, and the solution was acidified with dilute $\mathrm{HCl}$ to $\mathrm{pH}=2-3$. The precipitate was filtered off, washed once with water, and dried. The product was recrystallized from water to give $0.3 \mathrm{~g}(56 \%)$ of compound IIc. Mp ( $\left.{ }^{\circ} \mathrm{C}\right): 250$ (decomp); Rf: 0.54; ${ }^{1} \mathrm{H}$ NMR (DMSO-d 6 ): 3.29-3.34 (m, $2 \mathrm{H}$, $\left.\mathrm{S}(\mathrm{CH})_{2}\right), 4.30-4.36\left(\mathrm{~m}, 2 \mathrm{H}, \mathrm{S}(\mathrm{CH})_{2}\right), 7.10-7.22(\mathrm{~m}, 1 \mathrm{H}, \mathrm{NCH}) \mathrm{ppm}$; CHN analysis for $\mathrm{C}_{8} \mathrm{H}_{6} \mathrm{Br}_{1} \mathrm{~N}_{2} \mathrm{O}_{4} \mathrm{~S}_{1} \mathrm{~K}_{1}$; C 27.83; $\mathrm{H} 1.75 ; \mathrm{N}$ 8.11. Found C 27.70; H 1.70; N 7.96.

2-Bromo-1-(thietan-3-yl) imidazole-4,5-dicarboxylic acid di[(4dimethylaminophenyl) methylidenehydrazide] (IVa)

Compound III ( $0.39 \mathrm{~g}, 1.2 \mathrm{mmol})$ was dissolved in $2 \mathrm{ml}$ of dilute $\mathrm{HCl}$ and $20 \mathrm{ml}$ of ethanol, and 4-(dimethylamino) benzaldehyde $(0.53 \mathrm{~g}$, $3.6 \mathrm{mmol}$ ) in $5 \mathrm{ml}$ of ethanol was added. The reaction mixture was stirred for $10 \mathrm{~min}$ at room temperature. The precipitate was filtered off, washed with ethanol, and dried. The product was recrystallized from benzene to give $0.46 \mathrm{~g} \mathrm{(78 \% )}$ of compound IVa. Mp $\left({ }^{\circ} \mathrm{C}\right): 171$ 173 (decomp); Rf: 0.62; ${ }^{1} \mathrm{H} \mathrm{NMR}\left(\mathrm{CDCl}_{3}\right)$ : 3.38-3.44 (m, $\left.2 \mathrm{H}, \mathrm{S}(\mathrm{CH})_{2}\right)$, 4.44-4.50 (m, 2H, S(CH) $)$, 7.15-7.25 (m, 1H, NCH), $3.00(\mathrm{~s}, 6 \mathrm{H}$, $\left.\mathrm{N}\left(\mathrm{CH}_{3}\right)_{2}\right), 3.02\left(\mathrm{~s}, 6 \mathrm{H}, \mathrm{N}\left(\mathrm{CH}_{3}\right)_{2}\right), 6.68(\mathrm{~d}, \mathrm{~J}=8.1 \mathrm{~Hz}, 4 \mathrm{H}, \mathrm{Ar}-\mathrm{H}), 7.66-$ $7.70(\mathrm{~m}, 4 \mathrm{H}, \mathrm{Ar}-\mathrm{H}), 8.09(\mathrm{~s}, 1 \mathrm{H},=\mathrm{CH}), 8.27(\mathrm{~s}, 1 \mathrm{H},=\mathrm{CH}), 10.36(\mathrm{~s}, 1 \mathrm{H}$, $\mathrm{NH}), 14.23(\mathrm{~s}, 1 \mathrm{H}, \mathrm{NH}) \mathrm{ppm}$; CHN analysis for $\mathrm{C}_{26} \mathrm{H}_{29} \mathrm{Br}_{1} \mathrm{~N}_{8} \mathrm{O}_{2} \mathrm{~S}_{1}$; C 52.26; H 4.89; N 18.75. Found C 52.10; H 4.87; N 18.78.

2-Bromo-1-(thietan-3-yl) imidazole-4,5-dicarboxylic acid di[(4hydroxy-3-methoxyphenyl)methylidenehydrazide] (IVb)

Compound III ( $0.36 \mathrm{~g}, 1.0 \mathrm{mmol})$ was dissolved in $2 \mathrm{ml}$ of dilute $\mathrm{HCl}$ and $10 \mathrm{ml}$ of ethanol, and 3-methoxy-4-hydroxybenzaldehyde 0.46 $\mathrm{g}, 3.0 \mathrm{mmol}$ ) in $5 \mathrm{ml}$ of ethanol was added. The reaction mixture was stirred for $10 \mathrm{~min}$ at room temperature. The precipitate was filtered off, washed with ethanol and acetonitrile, and dried. The product was recrystallized from a 2:1 dimethylformamide-water mixture to give $0.59 \mathrm{~g}(98 \%)$ of compound IVb. Mp $\left({ }^{\circ} \mathrm{C}\right): 243-244 ;$ Rf: $0.62 ;{ }^{1} \mathrm{H}$ NMR (DMSO- $\left.\mathrm{d}_{6}\right): 3.38-3.45\left(\mathrm{~m}, 2 \mathrm{H}, \mathrm{S}(\mathrm{CH})_{2}\right), 4.21-4.27(\mathrm{~m}, 2 \mathrm{H}$, $\left.\mathrm{S}(\mathrm{CH})_{2}\right), 6.00-6.12(\mathrm{~m}, 1 \mathrm{H}, \mathrm{Z}-\mathrm{NCH}), 5.72-5.78(\mathrm{~m}, 1 \mathrm{H}, \mathrm{E}-\mathrm{NCH}), 3.81$ (s, $\left.3 \mathrm{H}, \mathrm{Z}-\mathrm{OCH}_{3}\right), 3.66\left(\mathrm{~s}, 3 \mathrm{H}, E-\mathrm{OCH}_{3}\right), 3.86\left(\mathrm{~s}, 3 \mathrm{H}, \mathrm{Z}-\mathrm{OCH}_{3}\right), 3.79(\mathrm{~s}, 3 \mathrm{H}$, $\left.E-\mathrm{OCH}_{3}\right), 6.82-6.88(\mathrm{~m}, 2 \mathrm{H}, \mathrm{Z}-\mathrm{Ar}-\mathrm{H}), 6.70-6.73(\mathrm{~m}, 2 \mathrm{H}, E-\mathrm{Ar}-\mathrm{H}), 7.04$ (d,J = 8.2 Hz, 1H, Z-Ar-H), $7.16(\mathrm{~d}, \mathrm{~J}=8.1 \mathrm{~Hz}, 1 \mathrm{H}, \mathrm{Z}-\mathrm{Ar}-\mathrm{H}), 7.38(\mathrm{~s}, 1 \mathrm{H}$, Z-Ar-H), 7.28 (s, 1H, Z-Ar-H), 7,21 (s, 1H, E-Ar-H), 8.18 (s, 1H, Z$=\mathrm{CH}), 7.96(\mathrm{~s}, 1 \mathrm{H}, E-=\mathrm{CH}), 8.47(\mathrm{~s}, 1 \mathrm{H}, Z=\mathrm{CH}), 8.37(\mathrm{~s}, 1 \mathrm{H}, E-=\mathrm{CH})$, $9.58(\mathrm{~s}, 1 \mathrm{H}, Z-\mathrm{OH}), 9.48(\mathrm{~s}, 1 \mathrm{H}, E-\mathrm{OH}), 9.66(\mathrm{~s}, 1 \mathrm{H}, Z-\mathrm{OH}), 9.51(\mathrm{~s}, 1 \mathrm{H}$, $E-\mathrm{OH}$ ), 11.74 (s, 1H, Z-NH), 11.59 (s, 1H, E-NH), 12.51 (s, 1H, Z-NH), $12.22(\mathrm{~s}, 1 \mathrm{H}, E-\mathrm{NH}) \mathrm{ppm}$; CHN analysis for $\mathrm{C}_{24} \mathrm{H}_{23} \mathrm{Br}_{1} \mathrm{~N}_{6} \mathrm{O}_{6} \mathrm{~S}_{1}$; C 47.77; H 3.84; N 13.93. Found C 47.49; H 3.79; N 13.75.

Compound IVc was synthesised by the procedure described in [13].

\section{Antidepressant activity}

The present study evaluates the antidepressant-like activity of the compounds. The protocol was approved by the Committee on the Ethics of Animal Experiments of the Bashkir State Medical University. 173 white non-inbred male mice weighing 20 to $22 \mathrm{~g}$ were used in the study. The animals were randomly allocated into groups. Housing and handling of animals were performed according to the Guidelines for housing and breeding of laboratory animals in nurseries and experimental-biological clinics (vivariums) and their use in scientific, educational and production purposes, approved by the RAMS and the Ministry of Health of RF 03.04.2003. Ten thietanecontaining derivatives of 2-bromoimidazole-4,5-dicarboxylic acid (I, IIa-f, IVa-c) were studied.
The antidepressant activity was investigated in the tail suspension test (TST) [14] and forced swimming test (FST) [15]. These animal tests are used more widely to predict the antidepressant action. The exploratory activity, locomotor activity, and anxiety were studied in the open field test (OF) [16], which evaluates the animal behavior in a novel environment.

The animal behavior analysis was performed with the Brain Test software [17]. The total immobility time was evaluated in the TST and FST. Additionally, the index of depression was calculated using the FST results. The index of depression is the ratio of short periods of immobilisation (less than $6 \mathrm{~s}$ ) to the number of periods of active swimming. Individual behavior of animals in the OF test was considered as the set of discrete behavioral acts and postures: "moving", "sniffing", "rearing", "grooming", "movement on the spot", "hole", "recline against wall", "sitting", and "defecation". The normality of behaviour, exploratory activity (the sum of the patterns "sniffing", "moving", and "hole") and anxiety (the sum of the patterns "moving on the spot", "recline against the wall", and "rearing") were considered as integral criteria.

The compounds were administered to the animals once intraperitoneally (i. p.) at doses equimolar to imipramine (Egis Pharmaceuticals PLC, Hungary) used as the reference drug (10 $\mathrm{mg} / \mathrm{kg}$ ) $30 \mathrm{~min}$ before the start of the test. Before administration, the compounds were suspended with 1-2 drops of TWIN-80 in water for injections. Imipramine (the reference drug) was injected i. p. once 30 min before the test at the optimally effective animal dose of 10 $\mathrm{mg} / \mathrm{kg}$. The control animals received equivalent amounts of saline with TWIN-80.

Statistical analysis was performed with Statistica 7.0. Descriptive statistics included median (Me), 25 and 75 percentiles (Per). Kruskall-Wallis test and Wilcoxon-Mann-Whitney test were used for group comparison. The statistical analysis was performed at the significance level of $5 \%$ [18]. The acute toxicity (LD50) of the compounds was studied with adult non-inbred male mice, according to the method of Litchfield J. and Wilcoxon F. [19] in the modification of Prozorovskiy V.B. [20]. The compounds were suspended ex tempore and injected once i. $p$.

\section{RESULTS AND DISCUSSION}

\section{Chemistry}

The disodium (IIa) [12] and dipotassium (IIb) 2-bromo-1-(thietan-3-yl) imidazole-4,5-dicarboxylates were synthesized by the reaction of dimethyl 2-bromo-1-(thietan-3-yl)imidazole-4,5-dicarboxylate (I) with sodium or potassium hydroxide (Scheme 1). The monopotassium salt of 2-bromo-1-(thietan-3-yl) imidazole-4,5dicarboxylic acid (IIc) was prepared by acidifying an aqueous solution of dipotassium salt IIb with dilute hydrochloric acid to $\mathrm{pH}=$ 2-3. The structure of IIc was proved by ${ }^{1} \mathrm{H}$ NMR spectroscopy. The ${ }^{1} \mathrm{H}$ NMR spectrum of monopotassium salt IIc exhibiting multiplets for the two $\mathrm{S}(\mathrm{CH})_{2}$ groups in the ranges of 3.29-3.34 and 4.30-4.36 ppm and a multiplet for the NCH group in the range of 7.10-7.22 ppm. The ${ }^{1} \mathrm{H}$ NMR spectrum does not specify the location of the potassium cation; therefore, the structure of salt IIc is confirmed by singlecrystal X-ray diffraction. Fig. 1 shows the monomeric fragment of the monopotassium salt IIc (fig. 1a) and the arrangement of molecules in the crystal, which reflects its sheetlike structure (fig. 1b). This compound crystallises in the monoclinic system with space group $\mathrm{P} 21 / \mathrm{n}$. There are several types of potassium atoms with different coordination environments of potassium, namely $\mathrm{KN}_{1} \mathrm{O}_{4} \mathrm{~S}_{1}, \mathrm{KN}_{1} \mathrm{O}_{3}$, $\mathrm{KO}_{3}, \mathrm{KO}_{1} \mathrm{~S}_{1}$, and $\mathrm{KO}_{2}$.

A number of specific features can be distinguished in the ligand structure. The thietane ring has a folded conformation, the dihedral angle between the $\mathrm{C}_{10} \mathrm{C}_{8} \mathrm{C}_{9}$ and $\mathrm{C}_{10} \mathrm{~S}_{2} \mathrm{C}_{9}$ planes is $16.52(6)^{\circ}$. Note the presence of an intermolecular hydrogen bond, Br1 $\cdots \mathrm{H} 8$, with a length of $2.624 \AA$. The hydrogen atom $\mathrm{H} 1$ is hypervalent (fig. 1), the 04-H1 and $01-\mathrm{H} 1$ bond lengths being 1.174 and $1.232 \AA$, respectively $(0-0=2.402 \AA)$ (table 1,2$)$. 

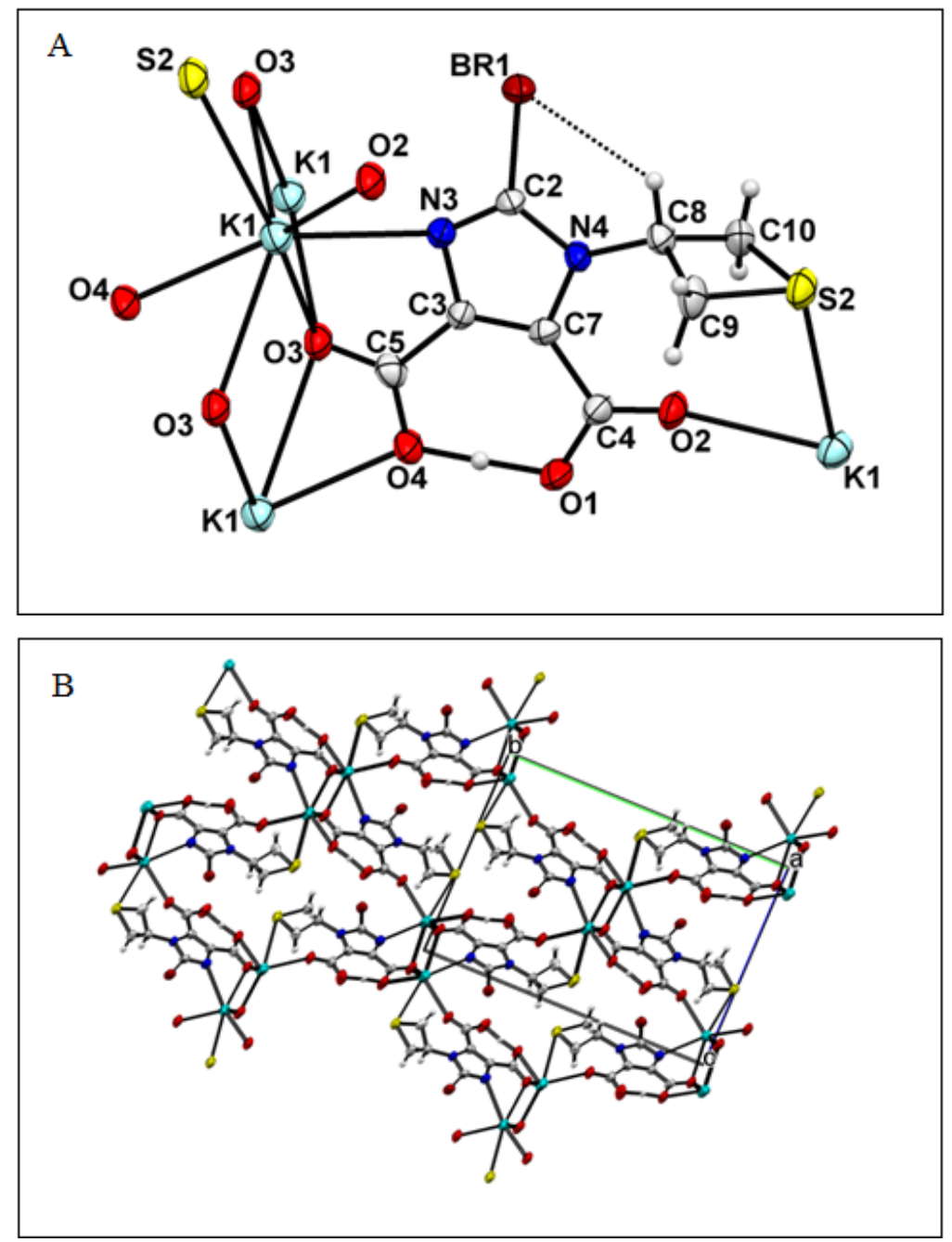

Fig. 1: (A) Monomeric fragment of IIc, (B) Sheet-like structure of IIc projected along $a$ axis

Table 1: Bond lengths for compound IIc

\begin{tabular}{|c|c|c|c|c|c|}
\hline Atom & Atom & Length/Å & Atom & Atom & Length/Å \\
\hline $\mathrm{Br}_{1}$ & $\mathrm{C}_{2}$ & $1.880(5)$ & $\mathrm{O}_{2}$ & $\mathrm{C}_{4}$ & $1.200(7)$ \\
\hline $\mathrm{K}_{1}$ & $\mathrm{~K}_{1}{ }^{1}$ & $3.745(3)$ & $\mathrm{O}_{3}$ & $\mathrm{~K}_{1}{ }^{2}$ & $2.947(4)$ \\
\hline $\mathrm{K}_{1}$ & $\mathrm{~K}_{1}{ }^{2}$ & $4.653(2)$ & $\mathrm{O}_{3}$ & $\mathrm{~K}_{1} 1$ & $2.788(4)$ \\
\hline $\mathrm{K}_{1}$ & $\mathrm{~S}_{2}{ }^{3}$ & $3.3973(19)$ & $\mathrm{O}_{3}$ & $\mathrm{C}_{5}$ & $1.238(7)$ \\
\hline $\mathrm{K}_{1}$ & $\mathrm{O}_{2}{ }^{3}$ & $2.684(4)$ & $\mathrm{O}_{4}$ & $\mathrm{~K}_{1}{ }^{2}$ & $2.767(4)$ \\
\hline $\mathrm{K}_{1}$ & $\mathrm{O}_{3}{ }^{1}$ & $2.788(4)$ & $\mathrm{O}_{4}$ & $\mathrm{C}_{5}$ & $1.278(6)$ \\
\hline $\mathrm{K}_{1}$ & $\mathrm{O}_{3}$ & $2.828(4)$ & $\mathrm{N}_{3}$ & $\mathrm{~K}_{1} 1$ & $3.401(5)$ \\
\hline $\mathrm{K}_{1}$ & $\mathrm{O}_{3}{ }^{2}$ & $2.947(4)$ & $\mathrm{N}_{3}$ & $\mathrm{C}_{2}$ & $1.287(7)$ \\
\hline $\mathrm{K}_{1}$ & $\mathrm{O}_{4}{ }^{2}$ & $2.767(4)$ & $\mathrm{N}_{3}$ & $\mathrm{C}_{3}$ & $1.374(6)$ \\
\hline $\mathrm{K}_{1}$ & $\mathrm{~N}_{3}{ }^{1}$ & $3.401(5)$ & $\mathrm{N}_{4}$ & $\mathrm{C}_{2}$ & $1.373(7)$ \\
\hline $\mathrm{K}_{1}$ & $\mathrm{~N}_{3}$ & $2.929(5)$ & $\mathrm{N}_{4}$ & $\mathrm{C}_{7}$ & $1.409(7)$ \\
\hline $\mathrm{K}_{1}$ & $\mathrm{C}_{5}{ }^{2}$ & $3.147(5)$ & $\mathrm{N}_{4}$ & $\mathrm{C}_{8}$ & $1.488(7)$ \\
\hline $\mathrm{K}_{1}$ & $\mathrm{C}_{5}$ & $3.530(5)$ & $\mathrm{C}_{3}$ & $\mathrm{C}_{5}$ & $1.492(7)$ \\
\hline $\mathrm{S}_{2}$ & $\mathrm{~K}_{1}{ }^{4}$ & $3.3973(19)$ & $\mathrm{C}_{3}$ & $\mathrm{C}_{7}$ & $1.367(7)$ \\
\hline $\mathrm{S}_{2}$ & $\mathrm{C}_{9}$ & $1.841(6)$ & $\mathrm{C}_{4}$ & $\mathrm{C}_{7}$ & $1.510(7)$ \\
\hline $\mathrm{S}_{2}$ & $\mathrm{C}_{10}$ & $1.838(6)$ & $\mathrm{C}_{5}$ & $\mathrm{~K}_{1}{ }^{2}$ & $3.147(5)$ \\
\hline $\mathrm{O}_{1}$ & $\mathrm{C}_{4}$ & 1.311(7) & $\mathrm{C}_{8}$ & $\mathrm{C}_{9}$ & $1.524(8)$ \\
\hline $\mathrm{O}_{2}$ & $\mathrm{~K}_{1}{ }^{4}$ & $2.684(4)$ & $\mathrm{C}_{8}$ & $\mathrm{C}_{10}$ & $1.524(8)$ \\
\hline
\end{tabular}

Symmetry code: ${ }^{1-X, 1-Y, 1-Z ; ~}{ }^{21-X, 1-Y, 1-Z ; ~}{ }^{3}-1 / 2+X, 1 / 2-Y,-1 / 2+Z ;{ }^{4} 1 / 2+X, 1 / 2-Y, 1 / 2+Z$

Table 2: Bond angles for compound IIc

\begin{tabular}{llllllll}
\hline Atom & Atom & Atom & Angle/ & Atom & Atom & Atom & Angle $^{\circ}$ \\
\hline $\mathrm{K}_{1}{ }^{1}$ & $\mathrm{~K}_{1}$ & $\mathrm{~K}_{1}{ }^{2}$ & $80.63(4)$ & $\mathrm{N}_{3}$ & $\mathrm{~K}_{1}$ & $\mathrm{C}_{5}{ }^{2}$ & $134.23(13)$ \\
$\mathrm{S}_{2}{ }^{3}$ & $\mathrm{~K}_{1}$ & $\mathrm{~K}_{1}{ }^{2}$ & $148.49(6)$ & $\mathrm{N}_{3}{ }^{1}$ & $\mathrm{~K}_{1}$ & $\mathrm{C}_{5}$ & $92.61(12)$ \\
\hline
\end{tabular}




\begin{tabular}{|c|c|c|c|c|c|c|c|}
\hline $\mathrm{S}_{2}{ }^{3}$ & $\mathrm{~K}_{1}$ & $\mathrm{~K}_{1} 1$ & $116.35(6)$ & $\mathrm{C}_{5}{ }^{2}$ & $\mathrm{~K}_{1}$ & $\mathrm{~K}_{1}{ }^{2}$ & 49.31(10) \\
\hline $\mathrm{S}_{2}{ }^{3}$ & $\mathrm{~K}_{1}$ & $\mathrm{~N}_{3}{ }^{1}$ & 89.11(8) & $\mathrm{C}_{5}$ & $\mathrm{~K}_{1}$ & $\mathrm{~K}_{1}{ }^{2}$ & $42.54(9)$ \\
\hline $\mathrm{S}_{2}{ }^{3}$ & $\mathrm{~K}_{1}$ & $\mathrm{C}_{5}$ & $168.95(10)$ & $\mathrm{C}_{5}{ }^{2}$ & $\mathrm{~K}_{1}$ & $\mathrm{~K}_{1} 1$ & $110.48(11)$ \\
\hline $\mathrm{O}_{2}{ }^{3}$ & $\mathrm{~K}_{1}$ & $\mathrm{~K}_{1}{ }^{1}$ & $132.11(11)$ & $\mathrm{C}_{5}$ & $\mathrm{~K}_{1}$ & $\mathrm{~K}_{1} 1$ & $58.22(9)$ \\
\hline $\mathrm{O}_{2}{ }^{3}$ & $\mathrm{~K}_{1}$ & $\mathrm{~K}_{1}{ }^{2}$ & $126.50(10)$ & $\mathrm{C}_{5}{ }^{2}$ & $\mathrm{~K}_{1}$ & $\mathrm{~S}_{2}{ }^{3}$ & $99.18(10)$ \\
\hline $\mathrm{O}_{2}{ }^{3}$ & $\mathrm{~K}_{1}$ & $\mathrm{~S}_{2}{ }^{3}$ & $63.08(9)$ & $\mathrm{C}_{5}{ }^{2}$ & $\mathrm{~K}_{1}$ & $\mathrm{~N}_{3} 1$ & $77.56(13)$ \\
\hline $\mathrm{O}_{2}{ }^{3}$ & $\mathrm{~K}_{1}$ & $\mathrm{O}_{3}{ }^{2}$ & $108.09(13)$ & $\mathrm{C}_{5}{ }^{2}$ & $\mathrm{~K}_{1}$ & $\mathrm{C}_{5}$ & $91.85(13)$ \\
\hline $\mathrm{O}_{2}{ }^{3}$ & $\mathrm{~K}_{1}$ & $\mathrm{O}_{3} 1$ & $103.67(13)$ & $\mathrm{C}_{9}$ & $\mathrm{~S}_{2}$ & $\mathrm{~K}_{1} 4$ & $108.4(2)$ \\
\hline $\mathrm{O}_{2}{ }^{3}$ & $\mathrm{~K}_{1}$ & $\mathrm{O}_{3}$ & $130.91(12)$ & $\mathrm{C}_{10}$ & $\mathrm{~S}_{2}$ & $\mathrm{~K}_{1} 4$ & $86.8(2)$ \\
\hline $\mathrm{O}_{2}{ }^{3}$ & $\mathrm{~K}_{1}$ & $\mathrm{O}_{4}{ }^{2}$ & $109.67(13)$ & $\mathrm{C}_{10}$ & $\mathrm{~S}_{2}$ & $\mathrm{C}_{9}$ & $78.1(3)$ \\
\hline $\mathrm{O}_{2}{ }^{3}$ & $\mathrm{~K}_{1}$ & $\mathrm{~N}_{3} 1$ & $149.56(12)$ & $\mathrm{C}_{4}$ & $\mathrm{O}_{2}$ & $\mathrm{~K}_{1} 4$ & $154.4(4)$ \\
\hline $\mathrm{O}_{2}{ }^{3}$ & $\mathrm{~K}_{1}$ & $\mathrm{~N}_{3}$ & $81.73(13)$ & $\mathrm{K}_{1} 1$ & $\mathrm{O}_{3}$ & $\mathrm{~K}_{1}$ & $83.65(11)$ \\
\hline $\mathrm{O}_{2}{ }^{3}$ & $\mathrm{~K}_{1}$ & $\mathrm{C}_{5}$ & $112.36(13)$ & $\mathrm{K}_{1} 1$ & $\mathrm{O}_{3}$ & $\mathrm{~K}_{1}{ }^{2}$ & $145.51(15)$ \\
\hline $\mathrm{O}_{2}{ }^{3}$ & $\mathrm{~K}_{1}$ & $\mathrm{C}_{5}{ }^{2}$ & $116.92(14)$ & $\mathrm{K}_{1}$ & $\mathrm{O}_{3}$ & $\mathrm{~K}_{1}{ }^{2}$ & $107.33(14)$ \\
\hline $\mathrm{O}_{3}$ & $\mathrm{~K}_{1}$ & $\mathrm{~K}_{1}{ }^{1}$ & $47.71(9)$ & $\mathrm{C}_{5}$ & $\mathrm{O}_{3}$ & $\mathrm{~K}_{1}{ }^{2}$ & $87.5(3)$ \\
\hline $\mathrm{O}_{3}{ }^{2}$ & $\mathrm{~K}_{1}$ & $\mathrm{~K}_{1} 1$ & $112.87(9)$ & $\mathrm{C}_{5}$ & $\mathrm{O}_{3}$ & $\mathrm{~K}_{1}$ & $114.7(3)$ \\
\hline $\mathrm{O}_{3}$ & $\mathrm{~K}_{1}$ & $\mathrm{~K}_{1}{ }^{2}$ & $37.20(8)$ & $\mathrm{C}_{5}$ & $\mathrm{O}_{3}$ & $\mathrm{~K}_{1} 1$ & $118.1(3)$ \\
\hline $\mathrm{O}_{3}{ }^{1}$ & $\mathrm{~K}_{1}$ & $\mathrm{~K}_{1}{ }^{2}$ & $126.11(9)$ & $\mathrm{C}_{5}$ & $\mathrm{O}_{4}$ & $\mathrm{~K}_{1}{ }^{2}$ & $95.0(3)$ \\
\hline $\mathrm{O}_{3}{ }^{2}$ & $\mathrm{~K}_{1}$ & $\mathrm{~K}_{1}{ }^{2}$ & $35.47(8)$ & $\mathrm{K}_{1}$ & $\mathrm{~N}_{3}$ & $\mathrm{~K}_{1} 1$ & $72.10(11)$ \\
\hline $\mathrm{O}_{3}{ }^{1}$ & $\mathrm{~K}_{1}$ & $\mathrm{~K}_{1} 1$ & $48.64(9)$ & $\mathrm{C}_{2}$ & $\mathrm{~N}_{3}$ & $\mathrm{~K}_{1} 1$ & $141.8(4)$ \\
\hline $\mathrm{O}_{3}$ & $\mathrm{~K}_{1}$ & $\mathrm{~S}_{2}{ }^{3}$ & $162.67(10)$ & $\mathrm{C}_{2}$ & $\mathrm{~N}_{3}$ & $\mathrm{~K}_{1}$ & $126.1(3)$ \\
\hline $\mathrm{O}_{3}{ }^{1}$ & $\mathrm{~K}_{1}$ & $\mathrm{~S}_{2}{ }^{3}$ & $68.14(9)$ & $\mathrm{C}_{2}$ & $\mathrm{~N}_{3}$ & $\mathrm{C}_{3}$ & $104.8(4)$ \\
\hline $\mathrm{O}_{3}{ }^{2}$ & $\mathrm{~K}_{1}$ & $\mathrm{~S}_{2}{ }^{3}$ & $115.46(9)$ & $\mathrm{C}_{3}$ & $\mathrm{~N}_{3}$ & $\mathrm{~K}_{1}{ }^{1}$ & $99.1(3)$ \\
\hline $\mathrm{O}_{3}$ & $\mathrm{~K}_{1}$ & $\mathrm{O}_{3}{ }^{2}$ & $72.67(14)$ & $\mathrm{C}_{3}$ & $\mathrm{~N}_{3}$ & $\mathrm{~K}_{1}$ & $107.4(3)$ \\
\hline $\mathrm{O}_{3}{ }^{1}$ & $\mathrm{~K}_{1}$ & $\mathrm{O}_{3}$ & $96.35(11)$ & $\mathrm{C}_{2}$ & $\mathrm{~N}_{4}$ & $\mathrm{C}_{7}$ & $104.0(4)$ \\
\hline $\mathrm{O}_{3}{ }^{1}$ & $\mathrm{~K}_{1}$ & $\mathrm{O}_{3}{ }^{2}$ & $145.51(15)$ & $\mathrm{C}_{2}$ & $\mathrm{~N}_{4}$ & $\mathrm{C}_{8}$ & $124.3(4)$ \\
\hline $\mathrm{O}_{3}{ }^{1}$ & $\mathrm{~K}_{1}$ & $\mathrm{~N}_{3} 1$ & $51.06(11)$ & $\mathrm{C}_{7}$ & $\mathrm{~N}_{4}$ & $\mathrm{C}_{8}$ & $131.3(4)$ \\
\hline $\mathrm{O}_{3}$ & $\mathrm{~K}_{1}$ & $\mathrm{~N}_{3} 1$ & $74.64(11)$ & $\mathrm{N}_{3}$ & $\mathrm{C}_{2}$ & $\mathrm{Br}_{1}$ & $122.5(4)$ \\
\hline $\mathrm{O}_{3}{ }^{1}$ & $\mathrm{~K}_{1}$ & $\mathrm{~N}_{3}$ & $83.40(13)$ & $\mathrm{N}_{3}$ & $\mathrm{C}_{2}$ & $\mathrm{~N}_{4}$ & $114.6(4)$ \\
\hline $\mathrm{O}_{3}$ & $\mathrm{~K}_{1}$ & $\mathrm{~N}_{3}$ & $56.45(12)$ & $\mathrm{N}_{4}$ & $\mathrm{C}_{2}$ & $\mathrm{Br}_{1}$ & $122.9(4)$ \\
\hline $\mathrm{O}_{3}{ }^{2}$ & $\mathrm{~K}_{1}$ & $\mathrm{~N}_{3} 1$ & $94.51(11)$ & $\mathrm{N}_{3}$ & $\mathrm{C}_{3}$ & $\mathrm{C}_{5}$ & $117.7(4)$ \\
\hline $\mathrm{O}_{3}{ }^{2}$ & $\mathrm{~K}_{1}$ & $\mathrm{C}_{5}$ & $75.30(12)$ & $\mathrm{C}_{7}$ & $\mathrm{C}_{3}$ & $\mathrm{~N}_{3}$ & $110.9(4)$ \\
\hline $\mathrm{O}_{3}$ & $\mathrm{~K}_{1}$ & $\mathrm{C}_{5}$ & $18.59(12)$ & $\mathrm{C}_{7}$ & $\mathrm{C}_{3}$ & $\mathrm{C}_{5}$ & $131.2(5)$ \\
\hline $\mathrm{O}_{3}{ }^{1}$ & $\mathrm{~K}_{1}$ & $\mathrm{C}_{5}$ & $104.72(13)$ & $\mathrm{O}_{1}$ & $\mathrm{C}_{4}$ & $\mathrm{C}_{7}$ & $114.6(5)$ \\
\hline $\mathrm{O}_{3}{ }^{1}$ & $\mathrm{~K}_{1}$ & $\mathrm{C}_{5}{ }^{2}$ & $125.89(14)$ & $\mathrm{O}_{2}$ & $\mathrm{C}_{4}$ & $\mathrm{O}_{1}$ & $123.1(5)$ \\
\hline $\mathrm{O}_{3}$ & $\mathrm{~K}_{1}$ & $\mathrm{C}_{5}{ }^{2}$ & $83.43(13)$ & $\mathrm{O}_{2}$ & $\mathrm{C}_{4}$ & $\mathrm{C}_{7}$ & $122.3(5)$ \\
\hline $\mathrm{O}_{3}{ }^{2}$ & $\mathrm{~K}_{1}$ & $\mathrm{C}_{5}{ }^{2}$ & $23.15(12)$ & $\mathrm{K}_{1}{ }^{2}$ & $\mathrm{C}_{5}$ & $\mathrm{~K}_{1}$ & $88.15(13)$ \\
\hline $\mathrm{O}_{4}{ }^{2}$ & $\mathrm{~K}_{1}$ & $\mathrm{~K}_{1}{ }^{2}$ & $72.64(8)$ & $\mathrm{O}_{3}$ & $\mathrm{C}_{5}$ & $\mathrm{~K}_{1}$ & $46.7(3)$ \\
\hline $\mathrm{O}_{4}{ }^{2}$ & $\mathrm{~K}_{1}$ & $\mathrm{~K}_{1} 1$ & $116.51(10)$ & $\mathrm{O}_{3}$ & $\mathrm{C}_{5}$ & $\mathrm{~K}_{1}{ }^{2}$ & $69.3(3)$ \\
\hline $\mathrm{O}_{4}{ }^{2}$ & $\mathrm{~K}_{1}$ & $\mathrm{~S}_{2}{ }^{3}$ & $75.94(8)$ & $\mathrm{O}_{3}$ & $\mathrm{C}_{5}$ & $\mathrm{O}_{4}$ & $122.7(5)$ \\
\hline $\mathrm{O}_{4}{ }^{2}$ & $\mathrm{~K}_{1}$ & $\mathrm{O}_{3}{ }^{2}$ & $45.34(11)$ & $\mathrm{O}_{3}$ & $\mathrm{C}_{5}$ & $\mathrm{C}_{3}$ & $118.4(4)$ \\
\hline $\mathrm{O}_{4}^{2}$ & $\mathrm{~K}_{1}$ & $\mathrm{O}_{3}$ & $103.98(12)$ & $\mathrm{O}_{4}$ & $\mathrm{C}_{5}$ & $\mathrm{~K}_{1}$ & $146.5(4)$ \\
\hline $\mathrm{O}_{4}^{2}$ & $\mathrm{~K}_{1}$ & $\mathrm{O}_{3}{ }^{1}$ & $110.76(13)$ & $\mathrm{O}_{4}$ & $\mathrm{C}_{5}$ & $\mathrm{~K}_{1}{ }^{2}$ & $61.2(3)$ \\
\hline $\mathrm{O}_{4}{ }^{2}$ & $\mathrm{~K}_{1}$ & $\mathrm{~N}_{3}$ & $158.03(12)$ & $\mathrm{O}_{4}$ & $\mathrm{C}_{5}$ & $\mathrm{C}_{3}$ & $118.9(5)$ \\
\hline $\mathrm{O}_{4}{ }^{2}$ & $\mathrm{~K}_{1}$ & $\mathrm{~N}_{3}{ }^{1}$ & $72.11(12)$ & $\mathrm{C}_{3}$ & $\mathrm{C}_{5}$ & $\mathrm{~K}_{1}$ & $80.1(3)$ \\
\hline $\mathrm{O}_{4}{ }^{2}$ & $\mathrm{~K}_{1}$ & $\mathrm{C}_{5}{ }^{2}$ & $23.87(12)$ & $\mathrm{C}_{3}$ & $\mathrm{C}_{5}$ & $\mathrm{~K}_{1}{ }^{2}$ & $149.0(3)$ \\
\hline $\mathrm{O}_{4}^{2}$ & $\mathrm{~K}_{1}$ & $\mathrm{C}_{5}$ & $114.97(12)$ & $\mathrm{N}_{4}$ & $\mathrm{C}_{7}$ & $\mathrm{C}_{4}$ & $122.6(5)$ \\
\hline $\mathrm{N}_{3} 1$ & $\mathrm{~K}_{1}$ & $\mathrm{~K}_{1}{ }^{1}$ & $48.10(8)$ & $\mathrm{C}_{3}$ & $\mathrm{C}_{7}$ & $\mathrm{~N}_{4}$ & $105.7(4)$ \\
\hline $\mathrm{N}_{3}{ }^{1}$ & $\mathrm{~K}_{1}$ & $\mathrm{~K}_{1}{ }^{2}$ & $83.62(8)$ & $\mathrm{C}_{3}$ & $\mathrm{C}_{7}$ & $\mathrm{C}_{4}$ & $131.7(5)$ \\
\hline $\mathrm{N}_{3}$ & $\mathrm{~K}_{1}$ & $\mathrm{~K}_{1}{ }^{2}$ & $85.46(9)$ & $\mathrm{N}_{4}$ & $\mathrm{C}_{8}$ & $\mathrm{C}_{9}$ & $118.1(5)$ \\
\hline $\mathrm{N}_{3}$ & $\mathrm{~K}_{1}$ & $\mathrm{~K}_{1}{ }^{1}$ & $59.80(10)$ & $\mathrm{N}_{4}$ & $\mathrm{C}_{8}$ & $\mathrm{C}_{10}$ & $117.8(5)$ \\
\hline $\mathrm{N}_{3}$ & $\mathrm{~K}_{1}$ & $\mathrm{~S}_{2}{ }^{3}$ & $125.83(9)$ & $\mathrm{C}_{10}$ & $\mathrm{C}_{8}$ & $\mathrm{C}_{9}$ & $99.0(4)$ \\
\hline $\mathrm{N}_{3}$ & $\mathrm{~K}_{1}$ & $\mathrm{O}_{3}{ }^{2}$ & $113.92(12)$ & $\mathrm{C}_{8}$ & $\mathrm{C}_{9}$ & $\mathrm{~S}_{2}$ & $90.2(4)$ \\
\hline $\mathrm{N}_{3}$ & $\mathrm{~K}_{1}$ & $\mathrm{~N}_{3} 1$ & $107.90(11)$ & $\mathrm{C}_{8}$ & $\mathrm{C}_{10}$ & $\mathrm{~S}_{2}$ & $90.3(4)$ \\
\hline $\mathrm{N}_{3}$ & $\mathrm{~K}_{1}$ & $\mathrm{C}_{5}$ & $43.43(12)$ & & & & \\
\hline
\end{tabular}

Symmetry code: ${ }^{1-X}, 1-Y, 1-Z ;{ }^{2} 1-X, 1-Y, 1-Z ;{ }^{3}-1 / 2+X, 1 / 2-Y,-1 / 2+Z ;{ }^{4} 1 / 2+X, 1 / 2-Y, 1 / 2+Z$

The reaction of 2-bromo-1-(thietan-3-yl) imidazole-4,5-dicarboxylic acid obtained in situ from the disodium salt Ila with amines gave 2bromo-1-(thietan-3-yl)imidazole-4,5-dicarboxylic acid salts IId-f (Scheme 1) [12].

2-Bromo-1-(thietan-3-yl) imidazole-4,5-dicarbohydrazide (III) was prepared by the reaction of dimethyl 2-bromo-1-(thietan-3yl)imidazole-4,5-dicarboxylates (I) with hydrazine hydrate (Scheme 1) [11]. The condensation of compound III with 4-(dimethylamino) benzaldehyde, 3-methoxy-4-hydroxybenzaldehyde, and 4bromoacetophenone gave the corresponding diylidenehydrazides of 2-bromo-1-(thietan-3-yl)imidazole-4,5-dicarboxylic acids IVa-c (Scheme 1) [13]. The structure of compound IVb was proved by ${ }^{1} \mathrm{H}$ NMR spectroscopy. The ${ }^{1} \mathrm{H}$ NMR spectrum of IVb exhibits doubled signals as two singlets for NH groups at $12.51(Z), 12.22(E)$ ppm and $11.74(Z), 11.59(E)$ ppm. The spectrum shows characteristic signals for thietane ring protons, the NCH group resonating in the 6.00-6.12 $(Z)$ and 5.72-5.78 $(E)$ ppm ranges, and the two $\mathrm{S}(\mathrm{CH})_{2}$ proton signals in the 4.21-4.27 and 3.38-3.45 ppm ranges. The spectrum also contains double proton signals for the 3-methoxy-4-hydroxybenzaldehyde residues.

\section{Antidepressant activity}

Screening for the presence of antidepressant activity revealed differently directed effects of the investigated derivatives on the immobilization parameters (the immobility time and the index of depression) in the TST and FST (table 3). It was demonstrated that only compound (IIb) significantly reduced the immobility time (by $59 \%, \mathrm{p}=0,025$ ) compared with the control in the TST. Other compounds, as well as the reference drug imipramine, caused a stable tendency of reducing this parameter. In addition, compound (IVa) 
caused a statistically significant reduction of the immobility time by $63 \%(p=0.0004)$ in the FST. The index of depression was significantly decreased under the action of I, IIb, IId-f, IVa, and IVc, in particular, by $21(\mathrm{p}=0.0115), 19(\mathrm{p}=0.027), 13(\mathrm{p}=0.034), 24(\mathrm{p}=0.002), 35(\mathrm{p}=$ $0.002), 17(p=0.048)$, and $19 \%(p=0.004)$, respectively. Imipramine reduced the index of depression by $17 \%(\mathrm{p}-0.004)$. A statistically significant reduction of both parameters (the immobility time and the index of depression) was observed only in the groups that received IIb and IVa (by 59\%, 19\% and 63\%, 19\%, respectively) (table 3). Therefore, the acute toxicity was studied for IIb and IVa. The compounds were injected with non-inbred male mice at a single i. p. dose of 200, 400, 600, 800, 1000, 1200, 1400, and $1600 \mathrm{mg} / \mathrm{kg}$. The animal behavior was assessed constantly during the first day. The death of animals was registered during $14 \mathrm{~d}$.

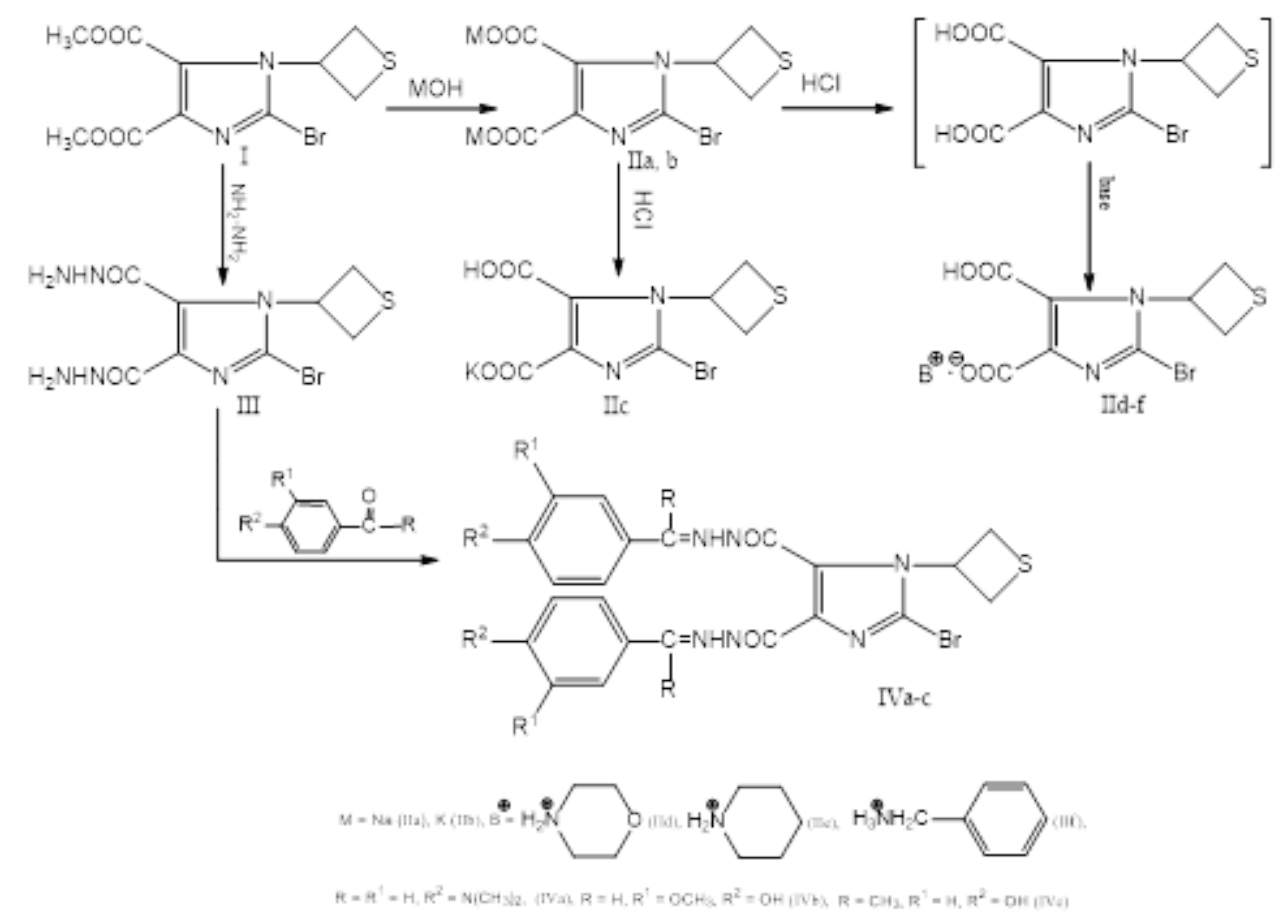

Scheme 1: Synthesis of 2-bromo-1-(thietan-3-yl) imidazole-4,5-dicarboxylic acid derivatives IIa-f, IVa-c

It was established that LD50 values of IIb and IVa were significantly lower than that of the reference drug imipramine. Compound IIb refers to hazard class $\mathrm{V}$ according to I. V. Berezovskaya's classification [21] (almost non-toxic compound). The LD50 of IVa was not reached, because there were no animal deaths, even after the injection of the maximal possible dose $(1600 \mathrm{mg} / \mathrm{kg}$ i. p. $)$. Imipramine is moderately toxic for the same route of administration (hazard class III) (table 4).

To exclude "false positive" results of the TST and FST, compounds I, Ila-f, and IVa-c were studied in the OF-test (fig. 2-6). The compounds were injected in male mice as single i. p. doses $30 \mathrm{~min}$ before the test. The doses were the same as the doses used in the TST and FST (table 3). It was discovered that IIb and IVa did not significantly modify the behavior of animals in the OF-test. Both integral criteria (exploratory activity and anxiety) and basic behavioral patterns were comparable with those for the control group, except "movement on the spot" and "defecation". These two patterns significantly decreased in the group that received compound IIb, but in the control group, statistical significance was not observed (fig. 3). Compound IVb decreased the anxiety by $42 \%$ $(\mathrm{p}=0.018)$, the number of "moving" patterns by $24 \%$, and "recline against the wall" by $62 \%$ and increased "movement on the spot" by $42 \%$ in comparison with the control group (fig. 5). A significant increase in the pattern "movement on the spot", 50 and 58\%, was induced by compounds I and IId, respectively (fig. 4-5). There was a decrease in the number of "defecations" and a tendency of "grooming" to increase in the group of IIe compound (fig. 2). The obtained results indicate that compound IVb reduces statistically significantly the anxiety and locomotor activity. The compounds I, IIa-f, and IVa,c do not have sedative and/or stimulative effects. This means that the TST and the FST results show an antidepressant effect of thietane-containing 2-bromoimidazole-4,5-dicarboxylic acid derivatives.
Thus, all the studied compounds I, IIa-IIf, and IVa-c, showed antidepressant-like activity after single i. p. injection. Compounds IIb and IVa have the most pronounced effect comparable with that of imipramine. These two compounds are safer (IV-V class of toxicity) than imipramine (III class of toxicity) and are promising for further studies. In addition, compound IVb significantly reduced the anxiety and decreased the locomotor activity of male mice.

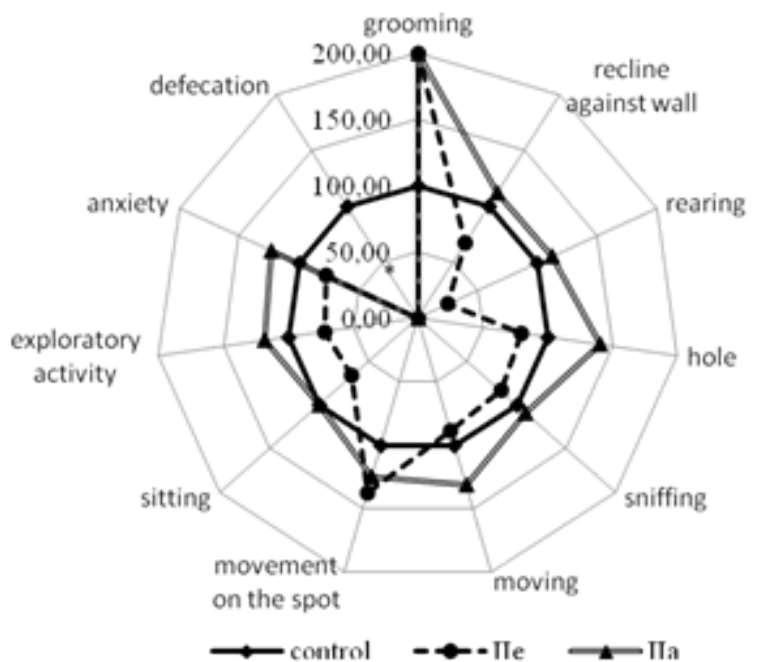

Fig. 2: Study of the influence of IIa and IIe in the OF-test, ${ }^{*}$-The difference is significant in comparison with control for IIe ( $p<0.05$ for Wilcoxon-Mann-Whitney U-test) 
Table 3: The effect of thietane-containing derivatives of 2-bromoimidazole-4,5-dicarboxylic acid on the parameters of TST and FST after single injection

\begin{tabular}{|c|c|c|c|c|}
\hline No. & Compounds (dose) & TST immobility time & FST immobility time & FST index of depression \\
\hline \multirow[t]{2}{*}{1.} & Control & $100.0(62.0-105.0)$ & $101.5(76.0-128.0)$ & $1.06(0.94-1.12)$ \\
\hline & & $\mathrm{n}=14$ & $\mathrm{n}=14$ & $\mathrm{n}=13$ \\
\hline \multirow[t]{2}{*}{2.} & Imipramine & $40.0(24.0-106.0)$ & $78.0 *(26.0-82.0)$ & $0.85 *(0.76-0.89)$ \\
\hline & $(10 \mathrm{mg} / \mathrm{kg})$ & $\mathrm{n}=15$ & $\mathrm{n}=13$ & $\mathrm{n}=13$ \\
\hline \multirow[t]{2}{*}{3.} & I & $77.0(34.5-141.5)$ & $122.5(96.0-147.0)$ & $0.80 *(0.72-0.89)$ \\
\hline & $(13 \mathrm{mg} / \mathrm{kg})$ & $\mathrm{n}=8$ & $\mathrm{n}=8$ & $\mathrm{n}=8$ \\
\hline \multirow[t]{2}{*}{4.} & IIa & $84.0(32.0-159.5)$ & $104.5(56.5-145.5)$ & $0.92 *(0.87-0.97)$ \\
\hline & $(13 \mathrm{mg} / \mathrm{kg})$ & $\mathrm{n}=8$ & $\mathrm{n}=8$ & $\mathrm{n}=8$ \\
\hline \multirow[t]{2}{*}{5.} & $\mathrm{IIb}$ & $41.0 *(20.0-68.0)$ & $75.0(51.5-96.5)$ & $0.83 *(0.73-0.91)$ \\
\hline & $(10 \mathrm{mg} / \mathrm{kg})$ & $\mathrm{n}=8$ & $\mathrm{n}=8$ & $n=7$ \\
\hline \multirow[t]{2}{*}{6.} & IIC & $90.5(63.5-225.5)$ & $69.0(69.0-75.0)$ & $0.87 *(0.84-1.0)$ \\
\hline & $(13 \mathrm{mg} / \mathrm{kg})$ & $\mathrm{n}=8$ & $\mathrm{n}=5$ & $\mathrm{n}=6$ \\
\hline \multirow[t]{2}{*}{7.} & IId & $68.0(48.0-157.5)$ & $99.0(65.0-122.0)$ & $0.78 *(0.61-0.80)$ \\
\hline & $(15 \mathrm{mg} / \mathrm{kg})$ & $\mathrm{n}=8$ & $\mathrm{n}=8$ & $\mathrm{n}=8$ \\
\hline \multirow[t]{2}{*}{8.} & IIe & $62.0(35.0-212.0)$ & $72.5(55.0-112.0)$ & $0.90 *(0.77-0.94)$ \\
\hline & $(15 \mathrm{mg} / \mathrm{kg})$ & $\mathrm{n}=8$ & $\mathrm{n}=8$ & $\mathrm{n}=8$ \\
\hline \multirow[t]{2}{*}{9.} & IIf & $64.5(38.0-110.0)$ & $126.0(102.5-154.0)$ & $0.67 *(0.53-0.79)$ \\
\hline & $(16 \mathrm{mg} / \mathrm{kg})$ & $\mathrm{n}=8$ & $\mathrm{n}=8$ & $\mathrm{n}=8$ \\
\hline \multirow[t]{2}{*}{10.} & IVa & $81.5(35.0-149.5)$ & $37.5^{*}(12.5-48.5)$ & $0.83 *(0.71-0.89)$ \\
\hline & $(21 \mathrm{mg} / \mathrm{kg})$ & $\mathrm{n}=8$ & $n=8$ & $\mathrm{n}=8$ \\
\hline \multirow[t]{2}{*}{11.} & $\mathrm{IVb}$ & $72.0(46.0-138.0)$ & $105.5(78.0-131.0)$ & $0.78 *(0.63-0.88)$ \\
\hline & $(23 \mathrm{mg} / \mathrm{kg})$ & $\mathrm{n}=8$ & $\mathrm{n}=8$ & $\mathrm{n}=8$ \\
\hline \multirow[t]{2}{*}{12.} & IVc & $85.5(59.0-106.5)$ & $86.5(57.0-113.0)$ & $0.86 *(0.83-0.96)$ \\
\hline & $(26 \mathrm{mg} / \mathrm{kg})$ & $\mathrm{n}=8$ & $\mathrm{n}=8$ & $\mathrm{n}=7$ \\
\hline 13. & Kruskal-Wallis test & $H(11 . N=109)=9.06 p=0.616$ & $H(11 . N=104)=28.52 p=0.003$ & $H(11 . N=102)=34.39 p=0.0003$ \\
\hline
\end{tabular}

Note: *-the difference is significant in comparison with control $(\mathrm{p}<0.05$ for Wilcoxon-Mann-Whitney U-test)

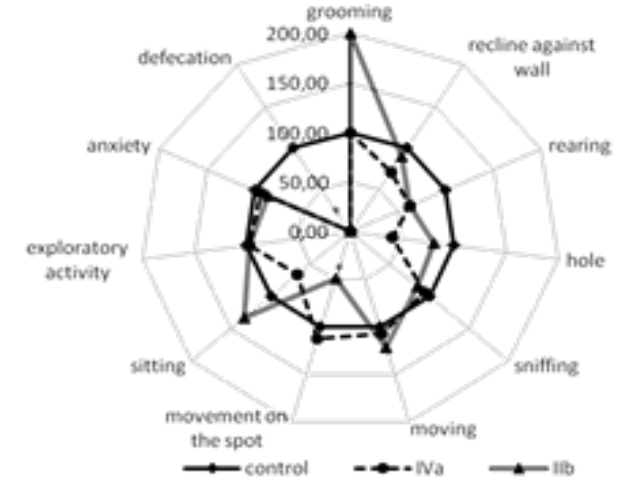

Fig. 3: Study of the influence of IIb and IVa in the OF-test, *-The difference is significant in comparison with control for IIb (p<0.05 for Wilcoxon-Mann-Whitney U-test)

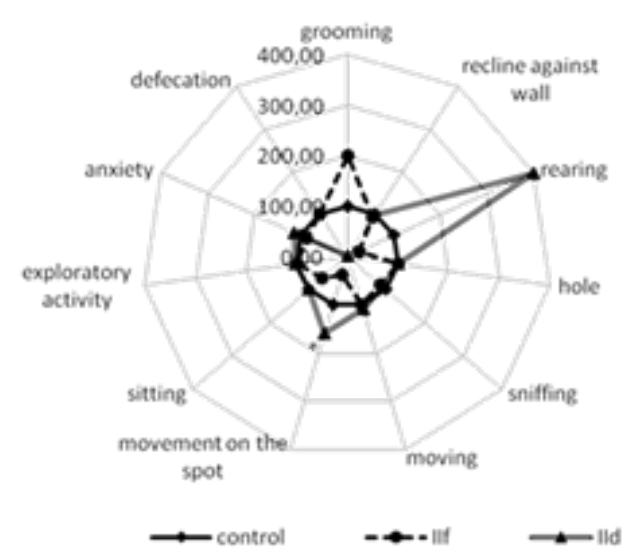

Fig. 4: Study of the influence of IId and IIf in the OF-test, *- The difference is significant in comparison with control for IId ( $<<0.05$ for Wilcoxon-Mann-Whitney U-test)

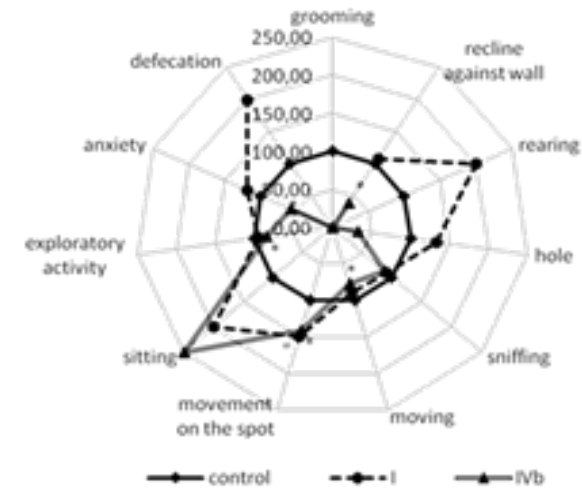

Fig. 5: Study of the influence of I and IVb in the OF-test

*- The difference is significant in comparison with control for IVb ( $p<0.05$ for Wilcoxon-Mann-Whitney U-test)

"- The difference is significant in comparison with control for I (p<0.05 for Wilcoxon-Mann-Whitney U-test)

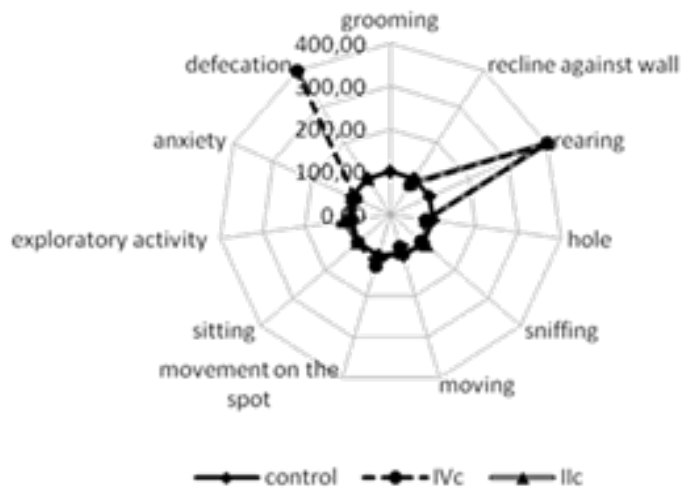

Fig.6: The study of the influence of IIc and IVc in the OF-test 
Table 4: The acute toxicity of compounds IIb, IVa, and imipramine for the single i. p. injection to male mice [21]

\begin{tabular}{lll}
\hline Compound & LD50, $\mathbf{~ m g} / \mathbf{k g}$ & Class/Degree of toxicity \\
\hline IIb & 1170 & IV/low toxicity \\
IVa & $>1600$ & V/Almost non-toxic \\
Imipramine & 68,4 & III/Moderately toxic \\
\hline
\end{tabular}

\section{CONCLUSION}

Salts and diylidenehydrazides of 2-bromo-1-(thietan-3-yl) imidazole-4,5-dicarboxylic acid were synthesized. The structure of synthesized compounds was confirmed by $1 \mathrm{H}$ NMR spectroscopy. The position of the potassium cation in the monopotassium salt of 2bromo-1-(thiethan-3-yl) imidazole-4, 5-dicarboxylic acid was determined by X-ray diffraction analysis. The most pronounced antidepressant effect comparable to imipramine is characteristic of dipotassium 2-bromo-1-(thietan-3-yl)imidazole-4,5-dicarboxylate and 2-bromo-1-(thietan-3-yl)imidazole-4,5-dicarboxylic acid di[(4dimethylaminophenyl) methylidenehydrazide], which is superior in safety and are promising for further investigation.

Thus, compounds with marked antidepressant activity were identified among the synthesized derivatives of 2-bromo-1-(thietan3-yl) imidazole-4,5-dicarboxylic acid. An obvious advantage of these compounds is low toxicity.

\section{AUTHORS CONTRIBUTION}

Professor Ferkat Khaliullin is the scientific leader in the synthesis of biologically active derivatives of 2-bromo-1-(thietan-3-yl)imidazole4,5-dicarboxylic acid, Ms. Anfisa Valieva is the direct executor of the synthesis of new derivatives of 2-bromo-1-(thietan-3-yl)imidazole4,5-dicarboxylic acid. Professor Irina Nikitina is the scientific leader in the study of antidepressant activity of newly synthesized compounds, Mrs. Albina Miftakhova played an important role in obtaining results on antidepressant activity. Professor Leonard Khalilov is the scientific leader in carrying out structural studies of new compounds, Mrs. Ekaterina Mescheryakova played an important role in conducting X-ray structural analysis with subsequent interpretation of the results.

\section{CONFLICT OF INTERESTS}

The authors declare that they have no conflict of interest

\section{REFERENCES}

1. Negwer M, Scharnow HG. Organic-chemical drugs and their synonyms extensively enlarged. $9^{\text {th }}$ ed. Vol. 1-7. Berlin: WileyVCH Verlag GmbH and Co; 2007.

2. Zhang N, Chen HM, Sood R, Kishna K, Fattom AI, Naso RB, et al. In vitro inhibition of the measles virus by novel ring-expanded ('fat') nucleoside analogues containing the imidazo [4,5-e] diazepine ring system. Bioorg Med Chem Lett 2002;12:3391-4.

3. Zhang P, Zhang N, Buckwold VE, Hosmane RS. Chemical and biological effects of substitution of the 2-position of ringexpanded ('fat') nucleosides containing the imidazo[4,5e][1,3] diazepine-4,8-dione ring system: The role of electronic and steric factors on glycosidic bond stability and anti-HCV activity. Bioorg Med Chem 2007;15:4933-45.

4. Premkumar T, Govindarajan S. Antimicrobial study of pyrazine, pyrazole and imidazole carboxylic acids and their hydrazinium salts. World J Microbiol Biotechnol 2005;21:479-80.
5. Nematollahi J, Guess W, Autian J. Imidazole carboxhydrazides. Chemistry and biological evalution. J Med Chem 1966;9:660-4.

6. Colman I, Ataullahjan A. Life course perspectives on the epidemiology of depression. J Can Psychiatr 2010;55:622-32.

7. Anki, Walia V. Influence of gender difference in the antidepressant effect of fluoxetine in mice in tail suspension test. Asian J Pharm Clin Res 2017;10:230-3.

8. Pendyala V, Babu Janga R, Suryadevara V. Phytochemical and pharmacological evaluation of commiphora mukul for antidepressant activity in albino mice. Asian J Pharm Clin Res 2017;10:360-3.

9. Agilent. Crys alis PRO. Agilent Technologies, Yarnton, Oxfordshire, England; 2012.

10. Sheldrick GM. A short history of SHELX. Acta Crystallogr Sect A: Found Adv 2008;A64:112-22.

11. Khaliullin FA, Valieva AR, Magadeeva GF. Hydrazinolysis of dimethyl 2-bromo-1-(thietan-3-yl)-1H-imidazole-4,5-dicarboxylates. Russ J Org Chem 2015;51:91-4.

12. Khaliullin FA, Valieva AR. Synthesis and structure of salts of 2bromo-1-(thietanyl-3) imidazole-4,5-dicarboxylic acid. Bashkir Chem J 2013;20:34-6.

13. Khaliullin FA, Valieva AR, Magadeeva GF. Synthesis and structure of diylidenhydrazides of 2-bromo-1-(thietanyl-3)imidazole-4,5dicarboxylic acid. Bashkir Chem J 2012;19:223-5.

14. Steru L, Chermat R, Thierry B, Simon P. The tail suspension test: a new method for screening antidepressants in mice. Psychopharmacology 1985;85:367-70.

15. Schetinin EV, Baturin VA, Arushanyan EB, Ovanesov KB, Popov AV. Biorythmological approach to the forced swim evaluation as an experimental model of "depressive" condition. Pavlov J Higher Nerv Act 1989;5:958-64.

16. Sestakova N, Puzserova A, Kluknavsky M, Bernatova I. Determination of motor activity and anxiety-related behaviour in rodents: methodological aspects and role of nitric oxide. Interdiscip Toxicol 2013;6:126-35.

17. Gabidullin RA, Ivanova OA, Nikitina IL, Alekhin EK. Certificate of state registration of the computer №2008610170. Moscow; 2008.

18. Glantz S. Biomedical statistics, translation from English. Moscow: Practice; 1998.

19. Litchfield JT, Wilcoxon FT. A simplified method of evaluating dose-effect experiments. J Pharmacol Exp Ther 1949;96:99-113.

20. Prozorovsky VB. Using the least-squares method for the analysis of probit mortality curves. Pharmakol Toksikol 1962;1:115-9.

21. Berezovskaya IV. Classification of substances with respect to acute toxicity for parenteral administration. Pharm Chem J 2003;37:139-41.

\section{How to cite this article}

- $\quad$ Ferkat Khaliullin, Irina Nikitina, Anfisa Valieva, Albina Miftakhova Ekaterina Mescheryakova, Leonard Khalilov. Synthesis and antidepressant activity of 2-bromo-1-(thietan-3-yl) imidazole-4,5dicarboxylic acid derivatives. Int $J$ Pharm Pharm Sci 2017;9(8):154-160. 